\title{
GMR
}

\section{Polymorphism of mitochondrial DNA in the Brazilian Canindé goat breed}

\author{
N.M.V. Silva' ${ }^{1}$, E.C. Pimenta Filho ${ }^{2}$, J.K.G. Arandas ${ }^{3}$, M.A. Gomes Filho ${ }^{4}$, \\ E. Ferreira ${ }^{5}$, I. Del Cerro ${ }^{5}$, C. Fonseca ${ }^{5}$ and M.N. Ribeiro ${ }^{3}$ \\ ${ }^{1}$ Programa de Doutorado Integrado em Zootecnia, Departamento de Zootecnia, \\ Universidade Federal da Paraíba, Areia, PB, Brasil \\ ${ }^{2}$ Departamento de Zootecnia, Universidade Federal da Paraíba, Areia, PB, Brasil \\ ${ }^{3}$ Programa de Doutorado Integrado em Zootecnia, Departamento de Zootecnia, \\ Universidade Federal Rural de Pernambuco, Recife, PE, Brasil \\ ${ }^{4}$ Departamento de Morfologia, Universidade Federal Rural de Pernambuco, \\ Recife, PE, Brasil \\ ${ }^{5}$ Departamento de Biologia \& CESAM, Universidade de Aveiro, Aveiro, Portugal \\ Corresponding author: M.N. Ribeiro \\ E-mail: ribeiromn1@hotmail.com
}

Genet. Mol. Res. 16 (2): gmr16029656

Received March 3, 2017

Accepted April 4, 2017

Published May 18, 2017

DOI http://dx.doi.org/10.4238/gmr16029656

Copyright $(2017$ The Authors. This is an open-access article distributed under the terms of the Creative Commons Attribution ShareAlike (CC BY-SA) 4.0 License.

\begin{abstract}
The success of the geographical distribution of goat populations around the world is a consequence of the adaptive potential of these breeds. Several relevant traits to the success of the species in colonizing different ecosystems (and use by man) evolved before domestication. These features were relevant for the selection of different breeds. Each breed represents a genetic heritage that may be unique and essential for maintaining the species. The objective of this study was to catalog the mtDNA haplotypes of the Brazilian autochthonous Canindé goat breed and to characterize the genetic diversity observed in subpopulations by sequencing a 481-bp fragment corresponding to the first portion of the control region in 178 individuals from 10 herds, sampled in six Brazilian states. The global population displays a total
\end{abstract}

Genetics and Molecular Research 16 (2): gmr16029656 
of 29 haplotypes and 56 polymorphic sites. About one-third (10) of the haplotypes were common to all subpopulations while the remaining (19) were exclusive to a single subpopulation. The population exhibited high average haplotype diversity (0.82), with maximum and minimum values of 0.90 and 0.56 in individual subpopulations, respectively. In contrast, nucleotide diversity was 0.014 , with maximum and minimum values of 0.020 and 0.004 , respectively. The spatial analysis of molecular variance did not detect structure within the Canindé goat breed, and analysis of molecular variance revealed that $88.4 \%$ of the variation observed in the population was due to differences among individuals in the same subpopulation. Only $11.4 \%$ of the genetic variation referred to differences among subpopulations. About one-third (33.1\%) of the individuals within population shared the same haplotype, which may be due not only to the breed developing from a small number of matrilines. The Brazilian autochthonous Canindé breed was classified as haplogroup A, a haplotype predominant in the Europe region.

Key words: Capra hircus; Hypervariable region; D-loop control region; Matrilineal marker

\section{INTRODUCTION}

Goats (Capra hircus) were introduced to the Americas in the century XVI, during the first decades of Portuguese and Spanish colonization (Primo, 2004). A wide diversity of local goat genetic groups developed along the path of the colonizers through Brazil. However, only the Canindé and Moxotó breeds are officially recognized. Ribeiro et al. (2004) cited Canindé as one of the main local breeds in northeastern Brazil, predominantly reared in extensive and multiplepurpose systems (meat, milk, and leather). The remaining populations are distributed among 12 herds from different Brazilian states (Bahia, Pernambuco, Paraíba, Rio Grande do Norte, Ceará, and Piauí) in the northeastern region, with higher density in the Rio Grande do Norte.

Some studies on the genetic diversity of the Canindé breed have been undertaken to examine the intra- and interpopulation variability in public and private herds (Menezes et al., 2006; Araújo et al., 2010). Ribeiro et al. (2012) studied the structure, diversity, and genetic relations between the Canindé breed and other Brazilian and Portuguese breeds using microsatellite markers. These authors found that the Canindé breed has specific alleles, but shares some alleles with other Portuguese breeds. However, these studies were not sufficient to infer the genetic origin of the Canindé breed, essential to infer the breed's maternal lineages. Genetic origin is usually inferred based on phylogeographic studies that discriminate the evolutionary history of maternal (Avise, 2000) and/or paternal lineages (Pérez et al., 2011), relating it to the geographical distribution mainly on the basis of the differences between the mitochondrial DNA (mtDNA) and Y chromosome sequences.

The first studies with mtDNA in goats were conducted by Luikart et al. (2001), Sultana et al. (2003), and Naderi et al. (2007), who identified four, six, and seven maternal lineages, respectively. These early studies constituted the basis for more specific regional studies. Oliveira (2007) analyzed a fragment of the D-loop region in goats from northeastern Brazil and Lopes et al. (2016) performed studies on Crespa ecotypes in southern Brazil, and the

Genetics and Molecular Research 16 (2): gmr16029656 
haplogroup A was predominant in the studied ecotypes. Haplotypes from Brazilian goat breeds are phylogenetically close to haplogroup A, which represents more than $90 \%$ of haplotypes worldwide (Taberlet et al., 2011) and has been widespread across the globe.

The largest portion of genetic diversity occurs in breeds with weak geographic structure due to the heavy transit of goats between continents, which is related to human migration and trade. This has taken place since ancient times, mainly because of the animals' ability to adapt and the ease with which they can be transported because of their small size (Pereira and Amorim, 2010).

Understanding breed development is crucial as it may help in choosing conservation and breeding strategies. In turn, cataloging a breed's mitochondrial variability is important, especially when considering the remaining genetic diversity, because of the potential use of a genetic source for the conservation of local genetic resources and the protection of the genetic resources of the country. Thus, the objective of this study was to catalog the mtDNA haplotypes of the Canindé breed and characterize the breed's genetic diversity by analyzing a fragment of the control region (D-loop) of the DNA.

\section{MATERIAL AND METHODS}

\section{Sampling and biological material collection sites}

The Ethics Committee approved the procedures used in the current experiment (Uso de Animais da Universidade Federal da Paraíba (CEUA-UFPB) No. 135/2015).

We sampled 178 Canindé goats (CAN), belonging to 10 herds (subpopulations) covering a vast geographic area in northeastern Brazil (Table S1). The number of sampled herds varied from state to state, according to goat density. Therefore, more herds were sampled in Rio Grande do Norte and Paraíba States.

\section{DNA extraction, amplification of the D-loop region, and sequencing}

Goat DNA was isolated from hair samples through alkaline extraction (Coelho et al., $2004)$ and was quantified using a spectrophotometer (NanoDrop ${ }^{\circledR}$, Thermo Scientific).

A 481-bp fragment of the first hypervariable segment (HVR1) of the control region (CR), corresponding to the region between 15,707 and $16,187 \mathrm{bp}$ of the mitochondrial DNA, was amplified from the 178 extracted DNA samples. Amplification was performed via polymerase chain reaction $(\mathrm{PCR})$ in $25-\mu \mathrm{L}$ reactions, containing $2.5 \mu \mathrm{L}$ reaction buffer $(2.5 \mathrm{X}$ stock solution, $1 \mathrm{X}$ final buffer concentration), $2.5 \mu \mathrm{L}$ BSA, $0.5 \mu \mathrm{L}$ dNTPs (10 mM of each), $1 \mu \mathrm{L}$ of each primer $(10 \mu \mathrm{M}), 0.2 \mu \mathrm{L}(1 \mathrm{U})$ Taq DNA polymerase, and $0.2 \mu \mathrm{L}$ genomic DNA $(50 \mathrm{ng} / \mu \mathrm{L})$. PCR amplification was performed according to Pereira et al. (2004), with some adaptations to the PCR conditions, and using the same forward (5'-CGCTCGCCTACACACAAATA-3') and reverse (5'-AAGAGTGGGCGATTTTAGG-3') primers. Amplification cycles were as follows: initial denaturation at $94^{\circ} \mathrm{C}$ for $3 \mathrm{~min} ; 38$ cycles at $94^{\circ} \mathrm{C}$ for $30 \mathrm{~s}$, at $60^{\circ} \mathrm{C}$ for $45 \mathrm{~s}$, and at $72^{\circ} \mathrm{C}$ for $1 \mathrm{~min}$; and a final extension at $72^{\circ} \mathrm{C}$ for $10 \mathrm{~min}$.

The products obtained were purified using a QIAquick PCR Purification Kit (Qiagen Inc., Valencia, CA, USA), following the protocols recommended by the manufacturers. The fragment of interest was sequenced in an ABI PRISM ${ }^{\circledR} 3730$-XL DNA Analyzer automatic sequencer (Applied Biosystems ${ }^{\mathrm{TM}}$ ), following the manufacturer's instructions and using the same PCR primers.

Genetics and Molecular Research 16 (2): gmr16029656 


\section{Data analysis}

Goat D-loop sequences were also retrieved from GenBank (http://www.ncbi.nlm. nih.gov/genbank/) were aligned and compared using MEGA ${ }^{\circledR} 6$ (Tamura et al., 2013). The sequences obtained were compared by alignment to the goat reference sequence AF533441 (Parma et al., 2003), following the criteria described in Pereira et al. (2004). Analysis involved 178 sequences from Brazilian Canindé goats, including 14 additional sequences of different goat haplogroups obtained from GenBank under the following accession numbers: A (AJ317736, AJ317661, and AJ317778; Luikart et al., 2001); B1 (AJ317826; Luikart et al., 2001) and (EF618355 and EF617850.1; Naderi et al., 2007); B2 (AJ317833; Luikart et al., 2001); C (AJ317835 Luikart et al., 2001) and (AB110559; Sultana et al., 2003); D (AB110587; Sultana et al., 2003) and (EF617701; Naderi et al., 2007); F (DQ241349; Sardina et al., 2006); and G (EF617728; Naderi et al., 2007) and (AF533441; Parma et al., 2003), and Capra pyrenaica (FJ207528; Hassanin et al., 2009) as outgroup. To include all the available sequence data in the phylogenetic analysis, sequences generated in this study were trimmed and only a 447-bp fragment, between 15,735 and 16,187 , was used in this analysis. The polymorphic sites, the number of haplotypes, haplotype diversity (h), and nucleotide diversity (p) were calculated using DnaSP 5.0 (Librado and Rozas, 2009), based on the total 481-bp fragment.

Analysis of molecular variance (AMOVA) was performed using Arlequin 3.5.1.2 (Excoffier and Lischer, 2010). The statistical significance of the $F_{\mathrm{ST}}$ values was estimated by permutation analysis, using 10,000 permutations. Spatial analysis of molecular variance (SAMOVA) was performed with SAMOVA 1.0 (Dupanloup et al., 2002) to investigate the distribution of genetic diversity throughout the entire dataset, using 100,000 permutations. Because three herds were located nearby in the municipality of Lajes, the three subpopulations were considered as one in SAMOVA.

Sequences were grouped by haplotype, and neighbor-joining tree (NJ) (Saitou and Nei, 1987) and maximum parsimony (MP) trees were generated using MEGA 6 package (Tamura et al., 2013) based on haplotypes, using a single sample by haplotype. The significance of the branches was evaluated after 1000 bootstrap replicates. The NJ tree of the subpopulations was edited using FigTree 1.4.2 (Rambaut, 2014). A median-joining network (Bandelt et al., 1999) of the haplotypes was generated using NETWORK 4.6.1 program (available at http://www. fluxus-engineer-ing.com/sharenet.htm).

\section{RESULTS}

\section{Polymorphism analysis}

The Canindé breed population exhibited many haplotypes $(\mathrm{H}=29)$, with 56 variable sites (Table 1 and Table S2). Oliveira (2007) analyzed a 130-bp fragment of the same mitochondrial region in 1531 sequences and found 55 polymorphic sites in goats from northeastern Brazil. Studies on goats from the Brazilian Crespa ecotype (Lopes et al., 2016), Portuguese goats (Pereira et al., 2005), Mediterranean goats (Hughes et al., 2012), Chinese goats (Zhong et al., 2013; Zhao et al., 2014), African goats (Kibegwa et al., 2016; Kadowaki et al., 2016), and goats of different regions worldwide (Naderi et al., 2007) were presented. The fragments of the D-loop region utilized in these studies varied from 130 to $696 \mathrm{bp}$, with 24 to 118 polymorphic sites.

Genetics and Molecular Research 16 (2): gmr16029656 
Our sample of 179 goats included 29 distinct haplotypes, with a haplotype diversity of 0.820 , a value higher than the values obtained for Crespa goats $(0.740)$ studied by Lopes et al. (2016) and lower than that observed by Liu et al. (2007) in Chinese goats (0.930). Haplotype diversity was high for each subpopulation (Table 1), ranging from 0.562 (Boa Vista-PB, PBB) to 0.900 (Lajes-K, RNL1).

Table 1. Genetic variability in the 10 Canindé goat subpopulations based on 481 -bp fragment sequences from
the D-loop region of the mtDNA.
\begin{tabular}{l|c|c|c|c}
\hline Subpopulation & N & mtDNA H & h & $\pi$ \\
\hline BA & 18 & 4 & 0.627 & 0.0045 \\
\hline PBT & 19 & 4 & 0.695 & 0.0090 \\
\hline PE & 10 & 6 & 0.888 & 0.0056 \\
\hline PBB & 18 & 6 & 0.562 & 0.0130 \\
\hline PI & 15 & 7 & 0.781 & 0.0102 \\
\hline CE & 18 & 6 & 0.849 & 0.0169 \\
\hline RNP & 20 & 6 & 0.810 & 0.0168 \\
\hline RNL1 & 20 & 11 & 0.900 & 0.0186 \\
\hline RNL2 & 20 & 7 & 0.789 & 0.0129 \\
\hline RNL3 & 20 & 7 & 0.857 & 0.0139 \\
\hline
\end{tabular}

Jeremoabo-BA (BA); Taperoá-PB (PBT); Floresta-PE (PE); Boa Vista-PB (PBB); Barro Duro-PI (PI); Sobral-CE (CE); Pedro Avelino-RN (RNP); Lajes-K (RNL1); Lajes-N (RNL2); Lajes-A (RNL3). N: sample size; H: number of haplotypes; h: haplotype diversity; and $\pi$ : nucleotide diversity.

The nucleotide diversity $(\pi)$ of the population was 0.0140 . The Jeremoabo-BA (BA) subpopulation exhibited the lowest nucleotide diversity $(\pi=0.0045)$, whereas the RNL1 population exhibited the highest value $(\pi=0.0186)$.

The nucleotide diversity observed in this study was lower than that found by Paiva et al. (2008), $0.0216 \pm 0.01146$, also in Canindé goats, at the Embrapa Sheep and Goat (Embrapa Caprinos) facility located in Sobral, Ceará State, Brazil.

The RNL1 subpopulation exhibited high h values and low $\pi$ (Table 1), whereas the others exhibited a combination of high haplotype diversity (Hd) and $\pi$ values, which may have been due to the sharing of females from different maternal lineages among the subpopulations. The nucleotide diversity was not directly proportional to the haplotype diversity since it is influenced by the haplotype frequencies.

\section{Distribution, frequency, and haplotype network}

Only $34.0 \%$ of the haplotypes was shared by the total population while a significant quantity of them (65.51\%) was exclusive to specific subpopulations (Figures 1 and 2). RNL2 and PI presented the greatest number of private haplotypes (six and four, respectively). The majority subpopulation showed at least one private haplotype, but the PBT subpopulation did not have exclusive haplotypes (Figures 1 and 2).

Haplotypes H_1 (33.13\%), H_2 (19.66\%), H_5 (11.79\%), and H_6 (10.11\%) were the most frequent. The $\mathrm{H} \_3, \mathrm{H} \_12, \mathrm{H} \_$17, $\mathrm{H} \_18, \mathrm{H} \_21$, and $\mathrm{H} \_28$ haplotypes showed ratios ranging from 1.68 to $3.37 \%$. The other haplotypes exhibited a frequency of $0.56 \%$, occurring in only a single individual and accounting for $10.74 \%$ of all the haplotypes obtained.

Only the H_1 haplotype was common to all of the subpopulations, present in 59 individuals. The $\mathrm{H}_{-} \mathbf{2}$ haplotype appeared in 35 individuals as the second most prevalent haplotype in the population, absent only in the PBB subpopulation. The $\mathrm{H} \_18$ was exclusive to

Genetics and Molecular Research 16 (2): gmr16029656 
CE subpopulation, present in three individuals. The H_21 was exclusive to both the RNL1 and RNL3 subpopulations. On the other hand, even belonging to the same state of the Federation, the subpopulation RNL2 showed a private haplotype (H_28) in five individuals. All of the haplotypes found belong to the A haplogroup, which is predominant across all continents (Figure 2).

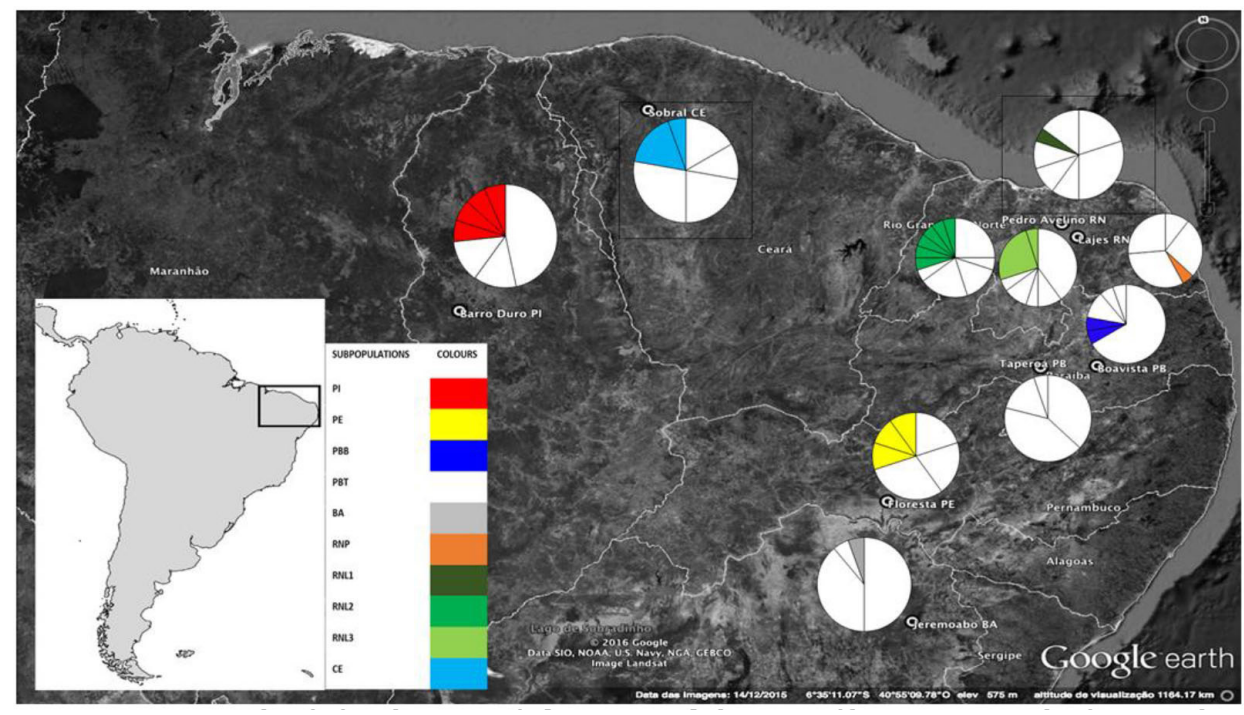

Figure 1. Geographical distribution and frequency of the Canindé goat mtDNA haplotype. The different colors are related to the geographical origin represents each exclusive haplotype of the subpopulation.

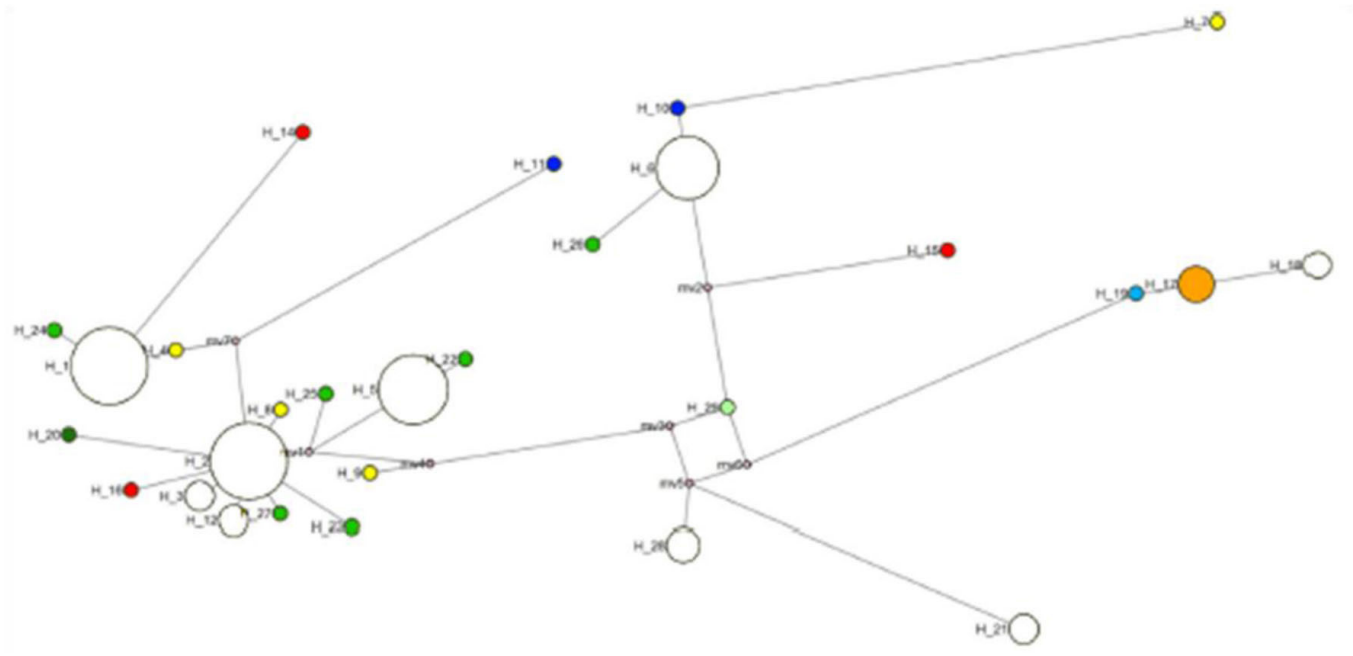

Figure 2. Relations among the Canindé goat haplotypes. The size of the circle is proportional to the number of individuals that have the respective haplotype. The small red circles indicate intermediate vectors, introduced by the algorithm executed.

Genetics and Molecular Research 16 (2): gmr16029656 
According to the haplotype network, it was possible to show that there was no trend of geographic or subpopulation structure, considering that the haplotypes of the different subpopulations were mixed (Figure 2).

The H_7, H_11, and H_14 haplotypes occur less frequently, occupying a peripheral position in the network, a characteristic that suggests a recent origin of these haplotypes in the population. Seven mean vectors were also identified in the haplotype network; these vectors suggest the possible existence of unsampled haplotypes or haplotypes corresponding to already extinct ancestral haplotypes.

\section{Genetic differentiation}

The estimated genetic differentiation among the 10 Canindé goat subpopulations, based on the $F_{\mathrm{ST}}$ fixation index for mtDNA, indicated less genetic differentiation between the RNL3 and BA populations, whereas animals from CE and BA exhibited higher genetic differentiation $\left(F_{\mathrm{ST}}=0.329\right)$ (Table 2$)$.

Table 2. Pairwise genetic distance estimates between 10 Canindé goat subpopulations based on $F_{\mathrm{ST}}$ measurements.

\begin{tabular}{l|c|c|c|c|c|c|c|c|c|c}
\hline Pop. & BA & PBT & PE & PBB & PI & CE & RNP & NRL1 & NRL2 & RNL3 \\
\hline BA & 0 & & & & & & & & & \\
\hline PBT & 0.023 & 0 & & & & & & & \\
\hline PE & $0.322^{*}$ & 0.191 & 0 & & & & & & \\
\hline PBB & 0.071 & 0.079 & 0.142 & 0 & & & & & & \\
\hline PI & -0.009 & -0.009 & 0.169 & -0.009 & 0 & & & & & \\
\hline CE & $0.328^{*}$ & $0.237^{*}$ & $0.220^{*}$ & $0.265^{*}$ & $0.250^{*}$ & 0 & & & & \\
\hline RNP & $0.239^{*}$ & 0.085 & 0.015 & 0.161 & 0.132 & $0.162^{*}$ & 0 & & & \\
\hline RNL1 & $0.134^{*}$ & 0.023 & 0.059 & 0.102 & 0.047 & $0.203^{*}$ & 0.013 & 0 & & \\
\hline RNL2 & $0.164^{*}$ & 0.055 & -0.009 & 0.063 & 0.057 & $0.181^{*}$ & -0.019 & -0.008 & 0 & \\
\hline RNL3 & 0.135 & 0.062 & 0.102 & 0.050 & 0.046 & $0.210^{*}$ & 0.068 & 0.038 & 0.018 & 0 \\
\hline
\end{tabular}

Jeremoabo-BA (BA); Taperoá-PB (PBT); Floresta-PE (PE); Boa Vista-PB (PBB); Barro Duro-PI (PI); Sobral-CE (CE); Pedro Avelino-RN (RNP); Lajes-K (RNL1); Lajes-N (RNL2); Lajes-A (RNL3). * Significant at P $<0.05$.

Most divergence $\left(F_{\mathrm{ST}}\right)$ values found among the subpopulation pairs were low to moderate, and not significant, revealing little genetic differentiation (Table 2). According to Wright (1931), $F_{\mathrm{ST}}$ values above 0.25 are indicators of strong differentiation. The higher significant genetic difference found in the CE subpopulation compared to the others may be explained by the fact that it is a relatively closed subpopulation, with a limited exchange.

The genetic differentiation of the subpopulations was also assessed using AMOVA, which also revealed a weak but significant genetic differentiation among the subpopulations, a finding strongly supported by the fixation index $\left(F_{\mathrm{ST}}=0.083 ; \mathrm{P}<0.05\right)$. Around $11.4 \%$ of the variation found in the sequences corresponds to the variation among the subpopulations, whereas $88.6 \%$ of the variation was assigned to the variation within subpopulations (Table 3 ). SAMOVA did not reveal any structure among subpopulations.

\section{Population dynamics}

The neutrality test $\left(F_{\mathrm{S}}\right)$ was significant when applied to each subpopulation and the entire population $\left(F_{\mathrm{S}}=-2.019 ; \mathrm{P}<0.05\right)$. In contrast, the Tajima index revealed significant differences only during the subpopulation analysis.

Genetics and Molecular Research 16 (2): gmr16029656 


\section{Table 3. AMOVA among the Canindé goat subpopulations.}

\begin{tabular}{l|c|c|c}
\hline Source of variation & Sum of squares & Variance components & Percentage variation \\
\hline Among subpopulations & 95.950 & 0.41745 & $11.4 \%$ \\
\hline Within subpopulations & 547.186 & 3.25907 & $88.6 \%$ \\
\hline Total & 643.136 & 3.67652 & $100.0 \%$ \\
\hline
\end{tabular}

\section{Phylogenetic tree construction}

A dendrogram was constructed with the $477 \mathrm{bp}$ of the 178 Canindé individuals belonging to the 10 subpopulations sampled, using C. pyrenaica as the outgroup (GenBank accession number FJ20528.1; Parma et al., 2003). The dendrogram shows that all of the Canindé goat samples belong to the A haplogroup, separate from the other haplogroups. Sequences referring to the $\mathrm{C}, \mathrm{F}$, and $C$. pyrenaica haplogroups appear at the base of the tree, followed by the clade with both B subgroups (B1 and B2). Next, the G haplogroup appears, and finally, the D haplogroup appears, more closely related to all of the other sequences, including the four sequences representative of the A haplogroup (Figure 3).

European haplotypes appear in the studied Canindé subpopulations, as shown in the haplotypes H17, H18, and H19, which belong to the A haplogroup (Figure 3). This is observed throughout the world, always at high frequencies (Sultana et al., 2003).

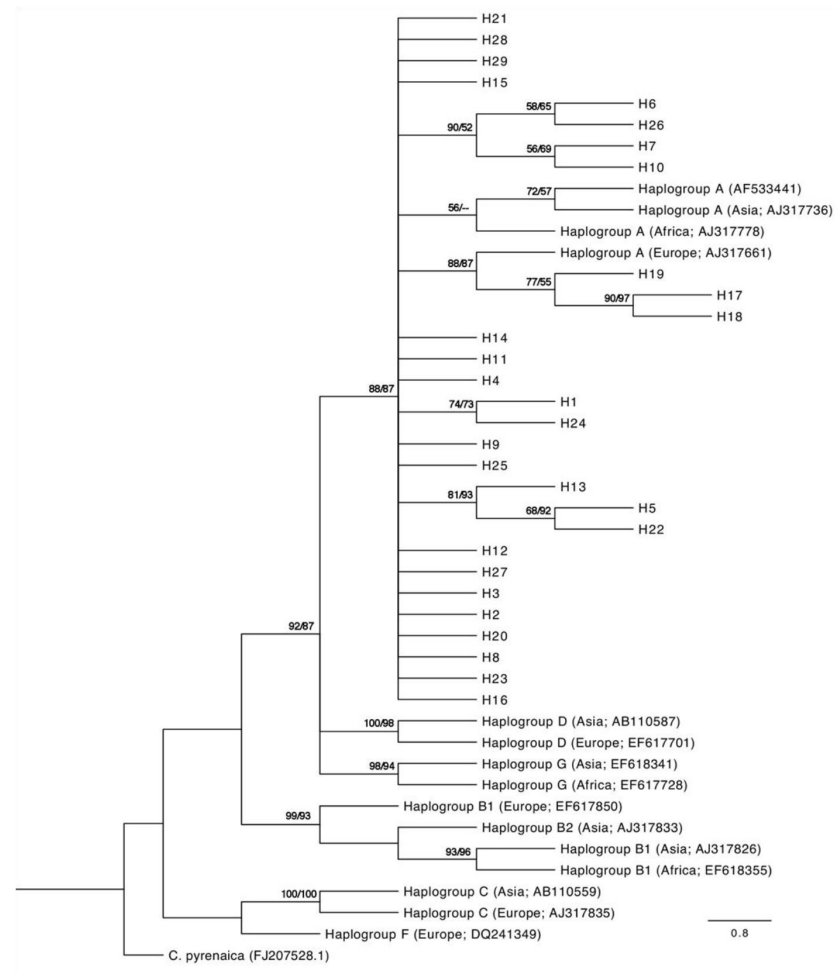

Figure 3. Dendrogram constructed based on 481-bp fragments from the HVR1 region of 178 Canindé goat mtDNA sequences, and representative of the six mtDNA haplogroups for goats (A; B1 and B2; C; D; F; and G) and $C$. pyrenaica. Values above the branches stand for the bootstrap support for NJ/MP phylogenies.

Genetics and Molecular Research 16 (2): gmr16029656 


\section{DISCUSSION}

The low nucleotide diversity and high haplotype diversity observed in this study may be evidence that the population underwent a genetic bottleneck followed by rapid growth, thereby accumulating mutations (Grant and Bowen, 1998). This diversity could be the result of the diverse goat groups introduced in northeastern Brazil during the colonization period.

According to breeders interviewed during sample collection, the genetic base of the Canindé breed came from several locations in northeastern Brazil, mainly from Bahia State. Thus, the subpopulations had the same genetic origin and were divided for anthropogenic reasons. Although most subpopulations exhibited numerous private haplotypes and lived hundreds of kilometers apart from each other, the lack of differentiation among them could be the result of original stock with a common origin. According to Luikart et al. (2001), weak geographic differentiation is common in livestock breeds due to the heavy flow of animals after domestication. Goats are easily transportable and manageable; therefore, these animals were commonly used as currency for exchange (Wang et al., 2015).

The diversity found in the major haplogroup $\mathrm{A}$ is the result of the initial domestication in the Fertile Crescent region, followed by an expansion throughout the world (Luikart et al., 2001). The European haplotypes appear in the Canindé subpopulations studied. This result is attributed to commercial trade that occurred during the colonial period and several animal introductions in Brazil over the years (Ribeiro et al., 2004). The results of the Canindé analyses are supported by the broad distribution of the A lineage, which is dominant throughout the world (Sultana et al., 2003; Naderi et al., 2007; Benjelloun et al., 2011; Zhong et al., 2013; Wang et al., 2015; Lopes et al., 2016; Kadowaki, et al., 2016; Kibegwa et al., 2016).

A consistent finding with all molecular markers is that genetic variability declines with increasing distance from the domestication centers. This has been shown for pigs, sheep, goats, cattle, and chickens (Groeneveld et al., 2010).

A large proportion of genetic variations (88.6\%) were distributed within the breed, and the differences among subpopulations within states were $11.4 \%$, indicating a weak phylogeographic structure in Canindé goats. Similar results were reported by Lopes (2012), who found $10.6 \%$ variation among Crespa goat populations, and by Oliveira (2007), who found $11.5 \%$ variation when comparing goats from northeastern Brazil with those from the Old World. Naderi et al. (2007) also reported that $77 \%$ of mtDNA variation is distributed within breeds. In African indigenous goats, very high percentage (99.9\%) of the total molecular variance was included in the within-breed component (Kibegwa et al., 2016).

While working with several Brazilian local goat breeds, Oliveira (2007) found a strong participation of European and African breeds in the formation of the Canindé populations. Lima and Loures (2010) point out that the European breeds, which came with the colonizers, were probably also influenced by African breeds brought on slave ships. Several routes were equally important for the introduction of animals to the Americas.

In the 19th century, modern standard breeds began to be introduced in Brazil. From 1925 until 1937, there were 387 animals of Toggenburg breeds from Switzerland, Murciana breeds from Spain, and Angora and Nubian breeds from South Africa (Ribeiro et al., 2004). Therefore, all these different influences, as well as the probable existence of a very distinct haplotype in the founding stock initially introduced in the region, contributed to the genetic diversity remaining in the Canindé goat breed.

Genetics and Molecular Research 16 (2): gmr16029656 


\section{CONCLUSIONS}

Based on analyses of the mtDNA D-loop region, no genetic or geographic structure was observed in the sample. The H1, H2, H5, and H6 haplotypes were the most frequent. Even with a reduced effective number, the Canindé breed exhibited mitochondrial variability, with higher variation among individuals than among subpopulations, which makes it possible to maintain the maternal lineages that contributed to forming the breed. The Brazilian Canindé population was classified as haplogroup A, with haplotypes predominantly of European descent. The Brazilian Canindé breed exhibited high haplotype diversity and low nucleotide diversity.

\section{Conflicts of interest}

The authors declare no conflict of interest.

\section{ACKNOWLEDGMENTS}

Eduardo Ferreira was supported by Fundação para a Ciência e Tecnologia, POPH, and European Union (Grant \#SFRH/BPD/72895/2010). We thank Rita Rocha for all the help in the laboratory. We would like to thank University of Aveiro (Department of Biology) and FCT/MEC for the financial support to CESAM UA - Centro de Estudos do Ambiente e do Mar da University of Aveiro (\#UID/AMB/50017) through national funds co-financed by the FEDER, within the PT2020 Partnership Agreement. Moreover, we thank Coordenação de Aperfeiçoamento de Pessoal de Nível Superior (CAPES) for the scholarship.

\section{REFERENCES}

Araújo AM, Beffa ML, Silva FLR and Costa M da S (2010). Monitoramento e caracterização molecular de genótipos locais de caprinos no Nordeste. In: Ciência e Tecnologia na pecuária de caprinos e ovinos (Gazzana JE, Alencar Júnior JS de, Farias LCE de, Oliveira OS de, et al., eds.). BND, Fortaleza, 382-398.

Avise JC (2000). Phylogeography: the history and formation of species. Harvard University Press, London.

Bandelt HJ, Forster P and Röhl A (1999). Median-joining networks for inferring intraspecific phylogenies. Mol. Biol. Evol. 16: 37-48 http://dx.doi.org/10.1093/oxfordjournals.molbev.a026036.

Benjelloun B, Pompanon F, Ben Bati M, Chentouf M, et al. (2011). Mitochondrial DNA polymorphism in Moroccan goats. Small Rumin. Res. 98: 201-205 http://dx.doi.org/10.1016/j.smallrumres.2011.03.041.

Coelho EGA, Oliveira DAA, Teixeira C, Sampaio IBM, et al. (2004). Comparação entre métodos de estocagem de DNA extraído de amostras de sangue, sêmen e pêlos e entre técnicas de extração. Arq. Bras. Med. Vet. Zootec. 56: 111-115 http://dx.doi.org/10.1590/S0102-09352004000100017.

Dupanloup I, Schneider S and Excoffier L (2002). A simulated annealing approach to define the genetic structure of populations. Mol. Ecol. 11: 2571-2581 http://dx.doi.org/10.1046/j.1365-294X.2002.01650.x.

Excoffier Land Lischer HEL (2010). Arlequin suite ver 3.5: a new series of programs to perform population genetics analyses under Linux and Windows. Mol. Ecol. Resour. 10: 564-567 http://dx.doi.org/10.1111/j.1755-0998.2010.02847.x.

Grant WS and Bowen BW (1998). Shallow Population Historiesin Deep Evolutionnary Lineages of Marine Fishhes: Insights From Sardines and Anchovies and Lesson for Coservatio. J. Hered. 89: 415-426. http://dx.doi.org/10.1093/ ihered/89.5.415

Groeneveld LF, Lenstra JA, Eding H, Toro MA, et al.; GLOBALDIV Consortium (2010). Genetic diversity in farm animals - a review. Anim. Genet. 41 (Suppl 1): 6-31 http://dx.doi.org/10.1111/j.1365-2052.2010.02038.x.

Hassanin A, Ropiquet A, Couloux A and Cruaud C (2009). Evolution of the mitochondrial genome in mammals living at high altitude: new insights from a study of the tribe Caprini (Bovidae, Antilopinae). J. Mol. Evol. 68: 293-310 http:// dx.doi.org/10.1007/s00239-009-9208-7.

Hughes S, Fernández H, Cucchi T, Duffraisse M, et al. (2012). A dig into the past mitochondrial diversity of Corsican

Genetics and Molecular Research 16 (2): gmr16029656 
goats reveals the influence of secular herding practices. PLoS One 7: e30272 http://dx.doi.org/10.1371/journal. pone. 0030272 .

Kadowaki S, Ohnishi K, Arai S, Guliyev F, et al. (2016). Mitochondrial DNA Analysis of Ancient Domestic Goats in the Southern Caucasus: A Preliminary Result from Neolithic Settlements at Göytepe and Hacı Elamxanlı Tepe. Int. J. Osteoarchaeol. http://dx.doi.org/10.1002/oa.2534.

Kibegwa FM, Githui KE, Jung'a JO, Badamana MS, et al. (2016). Mitochondrial DNA variation of indigenous goats in Narok and Isiolo counties of Kenya. J. Anim. Breed. Genet. 133: 238-247 http://dx.doi.org/10.1111/jbg.12182.

Librado P and Rozas J (2009). DnaSP v5: a software for comprehensive analysis of DNA polymorphism data. Bioinformatics 25: 1451-1452 http://dx.doi.org/10.1093/bioinformatics/btp187.

Lima ÍB and Loures AR 2010. Agricultura familiar: ovino-caprinocultura como fonte alternativa de renda, in: IN: 48 Congresso de Economia e Sociologia Rural (Org.). Anais SOBER, Campo Grande, 1-15.

Liu RY, Lei CZ, Liu SH and Yang GS (2007). Genetic diversity and origin of Chinese domestic goats revealed by complete mtDNA D-loop sequence variation. Asian-Australasian. J. Anim. Sci. 20: 178-183.

Lopes DD 2012. Variabilidade Genética, Estrutura populacional e Relações evolutivas de cabras crespas com base em marcadores moleculares microssatélites e DNA mitocondrial. Universidade Federal do Rio Grande do Sul.

Lopes DD, Fernández GP, Poli M, Moreira GRP, et al. (2016). Ancestry analysis of locally adapted Crespa goats from southernmost Brazil. Genet. Mol. Res. 15: 1-16 http://dx.doi.org/10.4238/gmr.15028324.

Luikart G, Gielly L, Excoffier L, Vigne J-D, et al. (2001). Multiple maternal origins and weak phylogeographic structure in domestic goats. Proc. Natl. Acad. Sci. USA 98: 5927-5932 http://dx.doi.org/10.1073/pnas.091591198.

Menezes MPC, Martinez AM, Ribeiro MN, Pimenta Filho EC, et al. (2006). Caracterização genética de raças caprinas nativas brasileiras utilizando-se 27 marcadores microssatélites. Rev. Bras. Zootec. 35: 1336-1341 http://dx.doi. org/10.1590/S1516-35982006000500012.

Naderi S, Rezaei H-R, Taberlet P, Zundel S, et al.; Econogene Consortium (2007). Large-scale mitochondrial DNA analysis of the domestic goat reveals six haplogroups with high diversity. PLoS One 2: e1012 http://dx.doi.org/10.1371/ journal.pone.0001012.

Oliveira JDDE 2007. Origem, distribuição e relação genética entre populações de Capra hircus do Nordeste do Brasil e sua relação com populações do Velho Mundo Origem, distribuição e relação genética entre populações de Capra hircus do Nordeste do Brasil e sua relação com p. FMRP.

Paiva SR, Barreto GB, Faria DA, da Silva FLR, et al. (2008). Uso de haplótipos de mtDNA na conservação das raças caprinas (Capra hircus) moxotó e canindé no nordeste do Brasil. Resumos do $54^{\circ}$ Congresso Brasileiro de Genética. 16 a 19 de setembro de 2008. Bahia Othon Palace Hotel, Salvador.

Pereira F and Amorim A 2010. Origin and Spread of Goat Pastoralism, ENCYCLOPEDIA OF LIFE SCIENCES \&. John Wiley \& Sons, Ltd., Chichester, UK. doi:10.1002/9780470015902

Pereira F, Pereira L, Van Asch B, Bradley DG, et al. (2005). The mtDNA catalogue of all Portuguese autochthonous goat (Capra hircus) breeds: high diversity of female lineages at the western fringe of European distribution. Mol. Ecol. 14: 2313-2318 http://dx.doi.org/10.1111/j.1365-294X.2005.02594.x.

Pereira L, Van Asch B and Amorim A (2004). Standardisation of nomenclature for dog mtDNA D-loop: a prerequisite for launching a Canis familiaris database. Forensic Sci. Int. 141:99-108 http://dx.doi.org/10.1016/j.forsciint.2003.12.014.

Pérez T, Hammer SE, Albornoz J and Domínguez A (2011). Y-chromosome phylogeny in the evolutionary net of chamois (genus Rupicapra). BMC Evol. Biol. 11: 272 http://dx.doi.org/10.1186/1471-2148-11-272.

Parma P, Feligini M, Greeppi G and Enne G (2003). The complete nucleotide sequence of goat (Capra hircus) mitochondrial genome. Goat mitochondrial genome. DNA Seq. 14: 199-203. http://dx.doi.org/10.1080/1042517031000089487

Primo AT 2004. América: Conquista e Colonização: A Fantástica História dos Conquistadores Ibéricos e Seus Animais na Era dos Descobrimentos. Porto Alegre, Brasil.

Rambaut A 2014. FigTree 1.4.2 software. Institute of Evolutionary Biology, Univ. Edinburgh. Available from: http://tree. bio.ed.ac.uk/ software/figtree/

Ribeiro MN, Urvola NG, Revidatti MA, Pacariote FA, et al. 2004. Conservação de raças caprinas nativas do Brasil: Histórico, situação atual e perspectivas. Impressa Universitária, Recife-PE.

Ribeiro MN, Bruno-de-Sousa C, Martinez-Martinez A, Ginja C, et al. (2012). Drift across the Atlantic: genetic differentiation and population structure in Brazilian and Portuguese native goat breeds. J. Anim. Breed. Genet. 129: 79-87 http://dx.doi.org/10.1111/j.1439-0388.2011.00942.x.

Saitou, N., Nei, M., 1987. The neighbor-joining method: a new method for reconstructing phylogenetic trees. Mol. Biol. Evol. 4, 406-25. doi:citeulike-article-id:93683

Sardina MT, Ballester M, Marmi J, Finocchiaro R, et al. (2006). Phylogenetic analysis of Sicilian goats reveals a new mtDNA lineage. Anim. Genet. 37: 376-378 http://dx.doi.org/10.1111/j.1365-2052.2006.01451.x.

Genetics and Molecular Research 16 (2): gmr16029656 
Sultana S, Mannen H and Tsuji S (2003). Mitochondrial DNA diversity of Pakistani goats. Anim. Genet. 34: 417-421 http:// dx.doi.org/10.1046/j.0268-9146.2003.01040.x.

Taberlet P, Coissac E, Pansu J and Pompanon F (2011). Conservation genetics of cattle, sheep, and goats. C. R. Biol. 334: 247-254 http://dx.doi.org/10.1016/j.crvi.2010.12.007.

Tamura K, Stecher G, Peterson D, Filipski A, et al. (2013). MEGA6: Molecular Evolutionary Genetics Analysis version 6.0. Mol. Biol. Evol. 30: 2725-2729 http://dx.doi.org/10.1093/molbev/mst197.

Wang GZ, Pi XS, Ji ZB, Qin ZJ, et al. (2015). Investigation of the diversity and origins of Chinese dairy goats via the mitochondrial DNA D-loop. J. Anim. Sci. 93: 949-955 http://dx.doi.org/10.2527/jas.2014-8420.

Wright S 1931. Evolution In mendellian populations, University. ed, Genetics. Chicago.

Zhao Y, Zhao R, Zhao Z, Xu H, et al. (2014). Genetic diversity and molecular phylogeography of Chinese domestic goats by large-scale mitochondrial DNA analysis. Mol. Biol. Rep. 41: 3695-3704 http://dx.doi.org/10.1007/s11033-0143234-2.

Zhong T, Zhao QJ, Niu LL, Wang J, et al. (2013). Genetic phylogeography and maternal lineages of 18 Chinese black goat breeds. Trop. Anim. Health Prod. 45: 1833-1837 http://dx.doi.org/10.1007/s11250-013-0432-1.

\section{Supplementary material}

Table S1. Geographical location of the Canindé subpopulations used in this study

Table S2. Polymorphic sites nucleotide (SNP) observed in the D-loop region of mtDNA between 178 Canindé goats in Northeast Brazil. Nucleotide positions are numbered according to the reference sequence, GenBank AF533441 (Parma et al., 2003). Identical sequences and deletions are represented by dots and dashes, respectively.

Genetics and Molecular Research 16 (2): gmr16029656 